\title{
First report of Potorolepis Spassky, 1994 (Eucestoda: Hymenolepididae) from China, with description of a new species in bats (Chiroptera: Rhinolophidae)
}

\author{
Tatiana A. Makarikova and Arseny A. Makarikov
}

Institute of Systematics and Ecology of Animals, Siberian Branch, Russian Academy of Sciences, Frunze Str. 11, 630091 Novosibirsk, Russia

\begin{abstract}
Potorolepis gulyaevi sp. n. (Cestoda: Hymenolepididae) is described from the Chinese horseshoe bat, Rhinolophus sinicus Andersen (Chiroptera: Rhinolophidae), from southern China. The new species differs from known species of the genus by the shape, number and size of rostellar hooks, the relative position and length of the cirrus-sac and the morphology of gravid uterus. This is the first report of a member of the genus from non-marsupial mammals and the first record of a Potorolepis Spassky, 1994 from eastern Asia. The generic diagnosis of Potorolepis is amended.
\end{abstract}

Keywords: Cestoda, Hymenolepididae, Potorolepis gulyaevi, new species, morphology, bats, Rhinolophus, China

Currently, majority of the hymenolepidid cestodes with armed rostellum parasitic in bats are included in the genus Vampirolepis Spassky, 1954 (Vaucher 1992, Sawada 1997). In addition to Vampirolepis, representatives of two other genera of hymenolepidids with an armed rostellum have been reported from bats, namely Staphylocystis Villot, 1877 and Rodentolepis Spassky, 1954 (Sawada 1997).

During a survey of the helminth fauna of Chiroptera in southern China (Yunnan Province), we found a previously unrecognized hymenolepidid species with an armed scolex in Chinese horseshoe bat, Rhinolophus sinicus Andersen. Based on morphological characteristics, this cestode differed from Vampirolepis, Staphylocystis and Rodentolepis. We attribute the specimen to the genus Potorolepis Spassky, 1994 (see Spassky 1994, Vaucher and Beveridge 1997) based on the characteristic hook shape, testes arranged in triangle, a fan-shaped ovary and a bilobed developing uterus.

At present, Potorolepis includes ten species which are regarded as specific parasites of dasyurid, peramelid and potoroid marsupials. Six species were described from Australia and one from Tasmania, and all had been originally placed in the genus Hymenolepis Weinland, 1858 (see Nybelin 1917, Beveridge and Barker 1975, Vaucher et al. 1984) and subsequently transferred to Potorolepis by Spassky (1994). Later, Vaucher and Beveridge (1997) described two additional species in marsupials from Aru Islands and New Guinea, including $P$. aruensis Vaucher et Beveridge, 1997 and P. woolleyae Vaucher et Beveridge, 1997; they also transferred P. peroryctis (Jones et Anderson,
1990) (syn.: Vampirolepis peroryctis Jones et Anderson, 1990) from the same locality to this genus. Additionally, Vaucher and Beveridge (1997) modified the generic diagnosis of Potorolepis with regard to the arrangement of the testes (either linear or triangular) and cirrus armature (armed or unarmed).

The new species discovered in Chinese bats is largely consistent with Potorolepis, but differs substantially from congeners in the shape, number and size of rostellar hooks, the relative position and length of the cirrus-sac, and morphology of gravid uterus. Comparative studies of Potorolepis, including this newly recognised species, revealed new details of morphology, which could be used as additional differential characters for the genus. Herein, we provide the description of a new species of Potorolepis and amend the generic diagnosis of the genus.

\section{MATERIALS AND METHODS}

A single cestode specimen was obtained from the small intestine of one of 18 Chinese horseshoe bats, Rhinolophus sinicus, collected in China (Yunnan Province). During June and July 2006 we examined 141 specimens of bats belonging to the genera Tadarida Rafinesque (1 specimen), Rhinolophus Lacépède (71), Miniopterus Bonaparte (6), Aselliscus Tate (3) and Myotis Kaup (52).

Bats were dissected within one hour after their death. The cestode specimen was isolated, washed and relaxed in water, and then fixed in $70 \%$ ethanol. It was stained in Ehrlich's haematoxylin, differentiated in a $3 \%$ aqueous solution of ferricammonium sulphate 12-hydrate, dehydrated in an ethanol series, cleared in clove oil and mounted in Canada balsam. The scolex 
and terminal proglottides were mounted separately in Berlese's medium to facilitate the examination of the rostellar hooks and eggs. The holotype was deposited in the helminthological collection of the Natural History Museum, Geneva, Switzerland (MHNG-PLAT). Measurements are given in micrometres unless otherwise stated, with mean and number of measurements in parentheses.

The following type materials and vouchers of previously described species were studied (all from MHNG-PLAT): type series of Potorolepis potoroi (Vaucher, Beveridge et Spratt, 1984) (holotype 14669, paratype 14670), P. bettongiae (Vaucher, Beveridge et Spratt, 1984) (holotype 14722, paratype 14723, vouchers 14724 (four slides)), Rodentolepis cercarteti (Vaucher, Beveridge et Spratt, 1984) (holotype 14401, paratypes 14402), P. peramelidarum (Nybelin, 1917) (vouchers 13870, 13871, 13478, 13479), P. antechini (Vaucher, Beveridge et Spratt, 1984) (holotype 13480), P. aklei (Beveridge et Barker, 1975) (vouchers 13873, 13471), P. bradleyi (vouchers 13483, 13874, 14672), P. isoodontis (Vaucher, Beveridge et Spratt, 1984 (paratype 14725).

\section{RESULTS}

\section{Potorolepis gulyaevi sp. n.}

Figs. 1, 2

Description (based on one specimen). Strobila of fully-developed gravid individual $112 \mathrm{~mm}$ long, maximum width $2.3 \mathrm{~mm}$ in posterior part of strobila. Strobila consisting of about 1000 craspedote proglottides. Segments wider than long. Strobilation gradual, with internal segmentation appearing prior to external segmentation.

Scolex rounded, 520 in diameter, weakly differentiated from neck (Fig. 1A). Suckers unarmed, cup-shaped, 170 $180 \times 160-170(175 \times 165, \mathrm{n}=4)$. Rhynchus short, armed with 15 rostellar hooks arranged in single row. Rostellar hooks (Fig. 1B) of diorchoid type, relatively large, 47$50(48.3, \mathrm{n}=11)$ long, with curved blade, 16-18 (16.8, $\mathrm{n}=11)$ long, longer than guard, 8.5-9.5 (9.1, $\mathrm{n}=11)$ long; guard situated almost perpendicular to blade; handle relatively long, 19-21 (19.8, $\mathrm{n}=11)$. Rostellum sac-like, 140 $\times 170$, situated in rostellar pouch, $210 \times 200$, slightly reaching beyond level of posterior margins of suckers. Neck 450 wide.

Two pairs of osmoregulatory canals, without transverse anastomoses. Dorsal osmoregulatory canals narrow, 4-5 $(4.6, n=5)$ wide, situated predominantly in same sagittal plane as ventral canals. Ventral osmoregulatory canals 24-30 (27, $\mathrm{n}=5)$ wide. Position of dorsal osmoregulatory canals not always constant; their loops may be situated lateral to ventral canals. Genital pores unilateral, dextral. Genital ducts pass dorsal to osmoregulatory canals (Fig. 1C, D). Development of proglottides gradual, protandrous. Strobilar part containing juvenile proglottides lacks external segmentation; proglottides become externally distinct at level of premature proglottides.

Male mature proglottides $110-130 \times 800-830$, with well-developed velum (Fig. 1C). Length/width ratio $1: 7$. Testes relatively large, usually three in number, almost equal in size, $117-160 \times 74-101(136 \times 85, \mathrm{n}=18)$, oval or pear-shaped, situated in triangle or, rarely, in row; poral testis separated from two antiporal testes by female gonads.

Hermaphroditic mature proglottides 102-130 × 1018$1100(116 \times 1054, \mathrm{n}=10)$, with well-developed velum (Fig. 1D). Testes 119-160 × 74-101 $(135 \times 85, \mathrm{n}=18)$, commonly situated in triangle or, rarely, in row. Cirrussac relatively short, $168-217 \times 31-38(189 \times 34, \mathrm{n}=10)$, antiporal part of cirrus-sac reaching ventral osmoregulatory canal, rarely overlapping or slightly crossing it (Fig. $1 \mathrm{D}, \mathrm{E})$. Genital atrium simple, $8-17 \times 6-9$, infundibular, deep, opens laterally about middle of lateral proglottis margin. No evaginated cirrus present in material studied. Invaginated cirrus $25-27 \times 6-7(26, \mathrm{n}=5)$, armed with small (less than 1 long) spines (Fig. 2A). Internal seminal vesicle ovoid, 90-134 × 25-31 $(109, \mathrm{n}=8)$, more than half of cirrus-sac length (Fig. 1E). External seminal vesicle transversely elongate, 74-125 × 34-44 $(95 \times 43, \mathrm{n}=8)$, clearly outlined from vas deferens, distinctly smaller than seminal receptacle.

Ovary 437-503 (457, $\mathrm{n}=15)$ wide, median, fanshaped, irregularly lobed, ventral to male genital organs, occupying substantial part of median field, overlapping testes (Fig. 1D). Vitellarium 137-153 × 47-76 (142 × 63, $\mathrm{n}=15)$, postovarian, median, scarcely lobed. Vagina tubular, clearly distinct from seminal receptacle, ventral to cirrus-sac. Copulatory part of vagina 24-25 × 4-6 (24.4 $\times 4.8, \mathrm{n}=5$ ), tubular, clearly distinct from seminal receptacle; ventral to cirrus-sac (Figs. 1E, 2A). Seminal receptacle transversely elongate, 416-489 × 72-110 (452 × 84, $\mathrm{n}=13$ ), reaching median line of proglottis.

Uterus first appears as perforated two-lobed sac, positioned dorsal to other organs and does not extend beyond osmoregulatory canals (Fig. 2B). With development of proglottides, uterus forms numerous diverticula on dorsal and ventral side (Fig. 2C, D). Testes remain in postmature proglottides; cirrus-sac and vagina persist in gravid proglottides. Gravid proglottides transversely elongate, 297-356 × 1900-2 $100(334 \times 1971, \mathrm{n}=10)$. Fully developed uterus occupies entire median field, does not extend beyond osmoregulatory canals, saccate, with one row or rarely two rows of ventral and dorsal diverticula; gravid uterus not perforated (Fig. 2D). Uterus contains numerous (up to 500) small oligolecithal eggs. Eggs 55-63 $\times$ 55-61 $(59 \times 58, \mathrm{n}=17)$, subspherical (Fig. 2E), with relatively thick outer coat (up to 4 in thickness); egg surface smooth; oncosphere 37-41 × 27-38 $(34 \times 31, \mathrm{n}=14)$. Embryophore subspherical, thin. Embryonic hooks 13-15 $(14, \mathrm{n}=14)$ long (Fig. 2F).

Type host: Chinese horseshoe bat (Rhinolophus sinicus Andersen) (Chiroptera, Rhinolophidae).

Type locality: Longxu Cave, near Fagudian village, Kunyang Town, Yunnan Province, China; ca. $24^{\circ} 30^{\prime} \mathrm{N} ; 102^{\circ} 20^{\prime} \mathrm{E}$.

Type material: Holotype: MHNG-PLAT 82283, collected on 17 June 2006. 
A

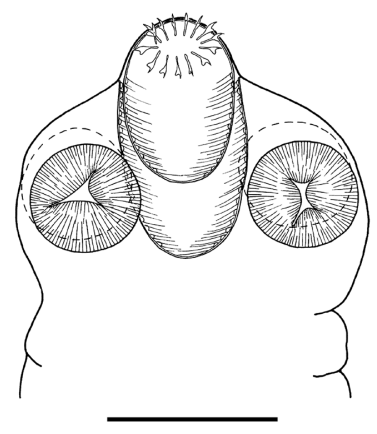

B

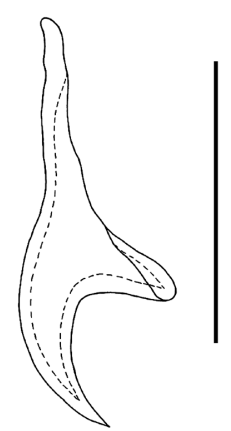

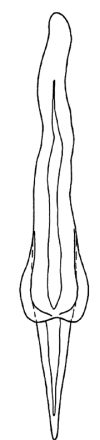

C

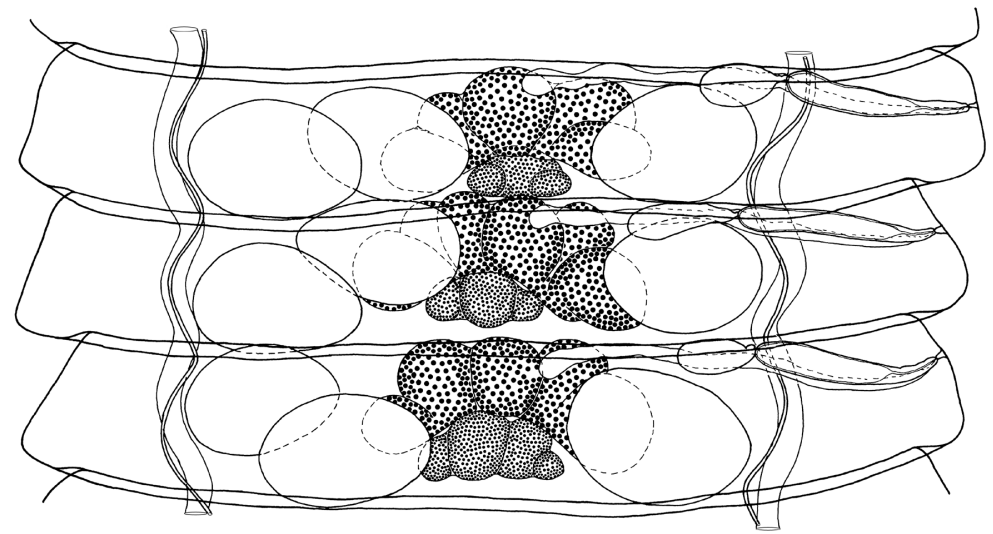

D
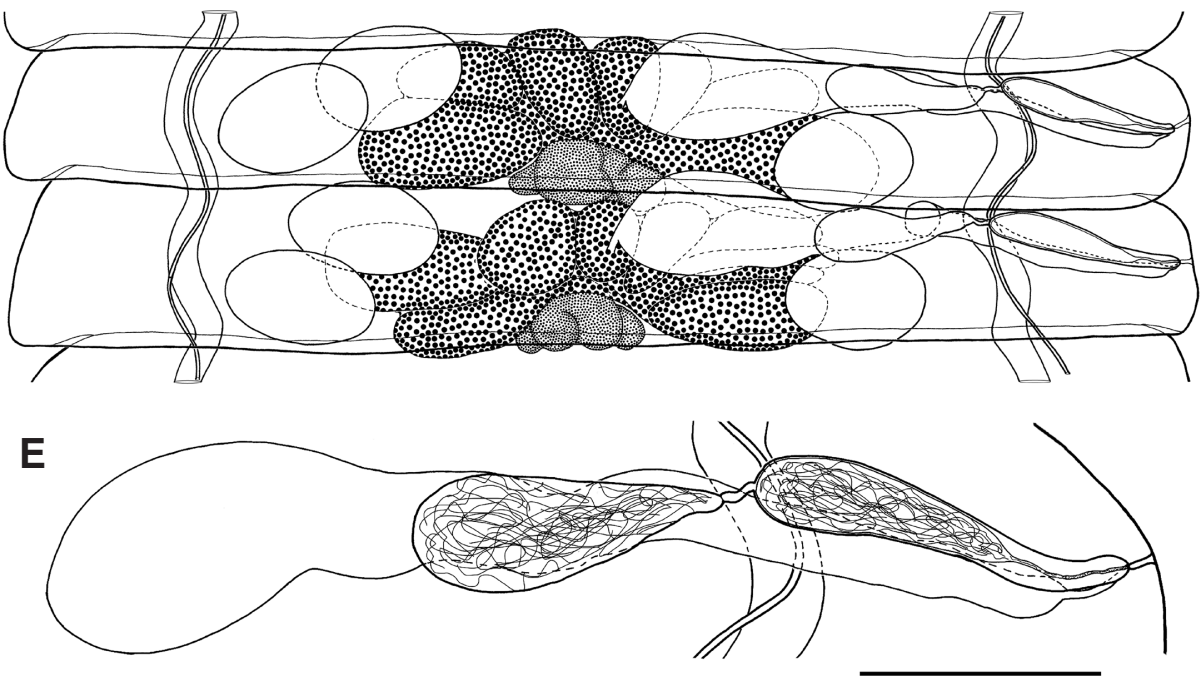

Fig. 1. Potorolepis gulyaevi sp. n. from Rhinolophus sinicus, China; holotype (MHNG-PLAT 82283). A - dorsoventral view of scolex; B - rostellar hooks in profile and view from posterior surface showing enlarged hook guard; C - male mature proglottides, from dorsal side; $\mathbf{D}$ - hermaphroditic mature proglottides, from dorsal side; $\mathbf{E}$ - genital ducts, from dorsal side. Scale bars: $\mathrm{A}=250 \mu \mathrm{m} ; \mathrm{B}=30 \mu \mathrm{m} ; \mathrm{C}, \mathrm{D}=300 \mu \mathrm{m} ; \mathrm{E}=100 \mu \mathrm{m}$.

Etymology: This species is named in honour of late Dr. Vladimir Gulyaev in recognition of his important contributions to studies on hymenolepidid cestodes.

Remarks. The specimen of Potorolepis gulyaevi sp. n. has the primary characters of Potorolepis, i.e. large diorchoid hooks, testes situated in triangle, fan-shaped ovary and bilobed developing uterus (see Spassky 1994, Vauch- er and Beveridge 1997). Among ten recognized species of Potorolepis, only P. aklei and P. aruensis have rostellar hooks similar in shape and number to those seen of P. gulyaevi (see Table 1). Rostellar hooks in the new species, however, are substantially smaller $(2 \times)$ than those of P. aklei and P. aruensis. Additionally, the ovary is wider and embryonic hooks in the oncosphere are significantly 
A

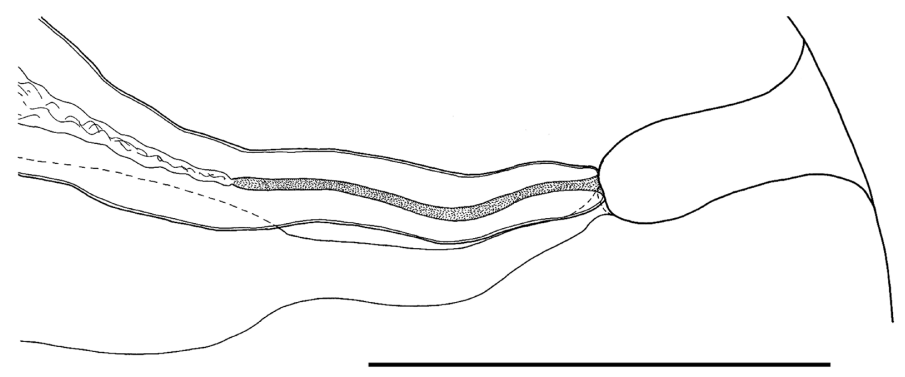

B

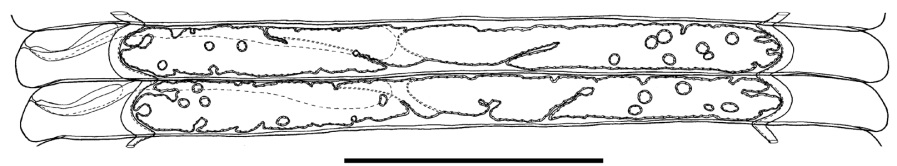

C
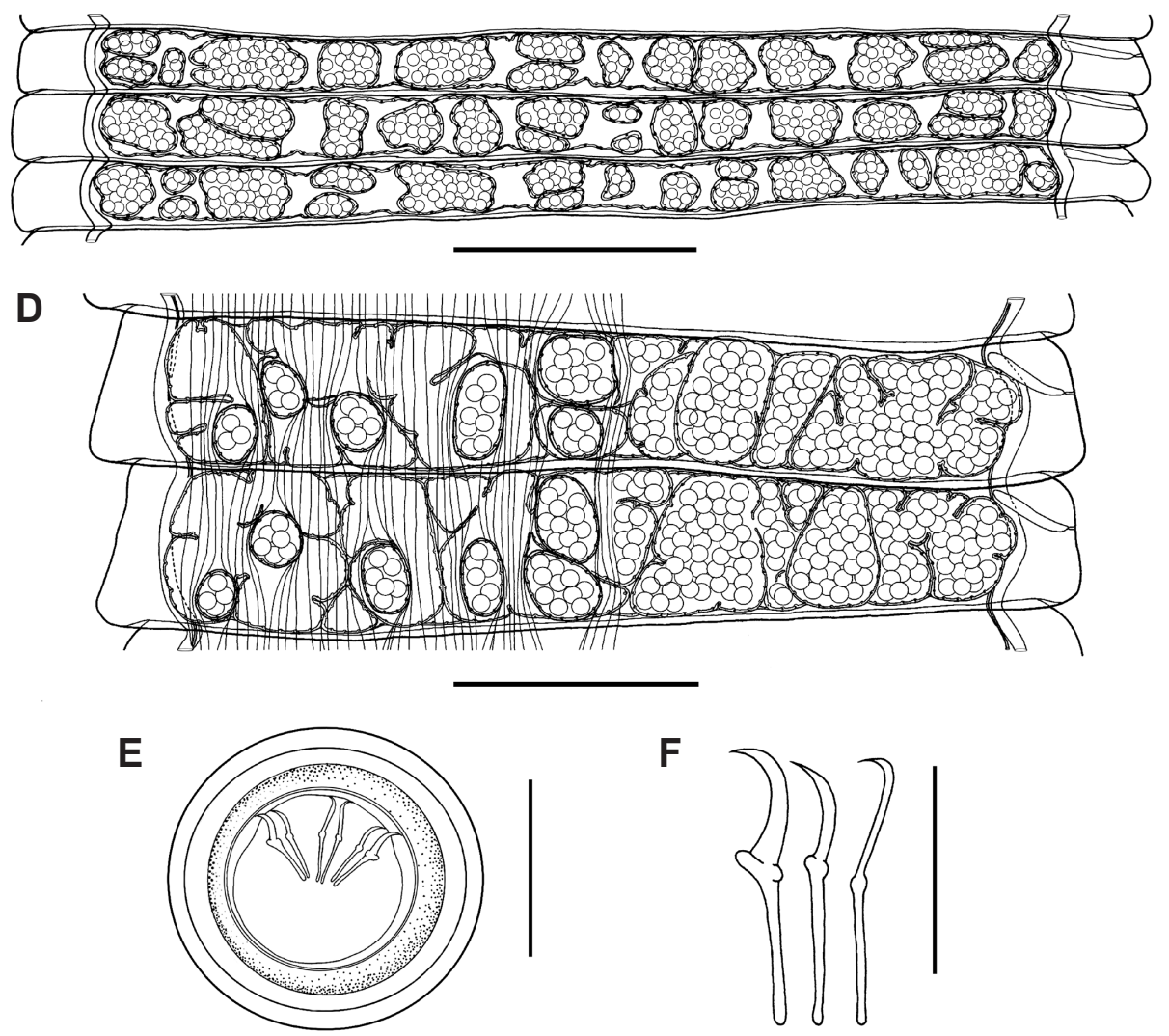

$\mathbf{F}$

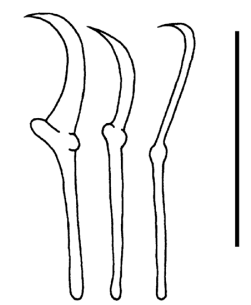

Fig. 2. Potorolepis gulyaevi sp. n. from Rhinolophus sinicus, China; holotype (MHNG-PLAT 82283). A - cirrus and vagina; B - postmature proglottides from dorsal side, showing uterus development; $\mathbf{C}$ - pregravid proglottides from dorsal side, showing appearance of uterine diverticula; D - gravid proglottides from dorsal side, showing saccate uterus with dorsal uterine diverticula (muscle fibres of the inner longitudinal musculature are illustrated only on the left side of the proglottis); $\mathbf{E}$ - egg; $\mathbf{F}$ - embryonic hooks. Scale bars: $\mathrm{A}=30 \mu \mathrm{m} ; \mathrm{B}-\mathrm{D}=500 \mu \mathrm{m} ; \mathrm{E}=30 \mu \mathrm{m} ; \mathrm{F}=10 \mu \mathrm{m}$.

smaller in P. gulyaevi compared to those of $P$. aklei. The cirrus-sac of $P$. gulyaevi is shorter than that of $P$. aruensis. Potorolepis gulyaevi is also distinguished from $P$. aruensis by its testes being arranged in a triangle; in the latter species the testes are situated in one row.

Currently, the genus Vampirolepis includes a number of poorly described species mainly from bats from south- eastern Asia (see Sawada 1997). We assume that Vampirolepis represents an artificial generic complex since some species placed in this genus do not correspond to its diagnosis (Spassky 1954, Vaucher 1992, Czaplinski and Vaucher 1994). To specify generic allocation of such species, it is necessary to re-examine their type materials because most of the original descriptions are inadequate. 
Table 1. Morphometric data distinguishing species of Potorolepis (measurements in micrometres unless otherwise stated).

\begin{tabular}{|c|c|c|c|c|c|c|c|c|c|c|c|}
\hline Characters & $\begin{array}{l}\text { P. peramel- } \\
\text { idarum }\end{array}$ & P. aklei & P. bradleyi & P. potoroi & $\begin{array}{l}\text { P. ante- } \\
\text { chini }\end{array}$ & $\begin{array}{l}\text { P. bettong- } \\
\text { iae }\end{array}$ & $\begin{array}{l}\text { P. isoodon- } \\
\text { tis }\end{array}$ & $\begin{array}{l}\text { P. pero- } \\
\text { ryctis }\end{array}$ & P. aruensis & $\begin{array}{l}\text { P. wool- } \\
\text { leyae }\end{array}$ & $\begin{array}{l}\text { P. gulyaevi } \\
\text { sp. n. }\end{array}$ \\
\hline Strobila: length (mm) & $60-130$ & $80-122$ & $80-135$ & 30 & $87-100$ & 160 & 60 & $12-15$ & 60 & 35 & 112 \\
\hline Strobila: width (mm) & $1.5-2$ & $1.1-1.6$ & $0.9-1.7$ & 1.4 & $0.9-1.2$ & 1.2 & 0.8 & 2.5 & $0.93-1.63$ & $0.76-0.9$ & 2.3 \\
\hline Scolex: width & $700-840$ & $370-510$ & $390-680$ & $409-665$ & - & $483-851$ & $590-900$ & $486-761$ & $520-650$ & $440-550$ & 520 \\
\hline Rostellum: size & - & $\begin{array}{l}130-200 \\
\times 100-170\end{array}$ & $\begin{array}{l}150-220 \\
\times 90-170\end{array}$ & $\begin{array}{l}180-206 \\
\times 117-188\end{array}$ & - & $\begin{array}{l}156-213 \\
\times 172-261\end{array}$ & $\begin{array}{l}166-245 \\
\times 130-278\end{array}$ & $240 \times 360$ & $\begin{array}{l}180-260 \\
\times 170-230\end{array}$ & $\begin{array}{l}130-200 \\
\times 190-280\end{array}$ & $140 \times 170$ \\
\hline Rostellar hooks: no. & $44-46$ & $11-17$ & $10-15$ & $29-33$ & $22-23$ & $24-27$ & $33-39$ & 40 & $16-18$ & $15-19$ & 15 \\
\hline Rostellar hook: length & 100 & $83-100$ & $103-128$ & $98-103$ & $56-59$ & 79-91 & $71-82$ & $124-192$ & $128-147$ & $163-182$ & $47-50$ \\
\hline Sucker: size & - & $110-180$ & $170-210$ & $\begin{array}{l}237-360 \\
\times 123-327\end{array}$ & - & $\begin{array}{l}212-466 \\
\times 183-376\end{array}$ & $\begin{array}{l}212-368 \\
\times 186-270\end{array}$ & $\begin{array}{l}212-466 \\
\times 183-376\end{array}$ & $\begin{array}{l}130-160 \\
\times 150-180\end{array}$ & $\begin{array}{l}130-210 \\
\times 100-190\end{array}$ & $\begin{array}{l}170-180 \\
\times 160-170\end{array}$ \\
\hline Cirrus-sac: size & 140 & $\begin{array}{l}130-210 \\
\times 20-40\end{array}$ & $\begin{array}{l}140-250 \\
\times 15-30\end{array}$ & $\begin{array}{l}228-293 \\
\times 55-80\end{array}$ & $115 \times 12$ & $\begin{array}{l}150-277 \\
\times 36-78\end{array}$ & $\begin{array}{l}81-168 \\
\times 29-71\end{array}$ & $\begin{array}{l}264-308 \\
\times 44-88\end{array}$ & $\begin{array}{l}270-420 \\
\times 40-50\end{array}$ & $\begin{array}{l}140-170 \\
\times 36-42\end{array}$ & $\begin{array}{l}168-217 \\
\times 31-38\end{array}$ \\
\hline Testes: size & $130-180$ & $100-180$ & $80-110$ & - & - & - & - & $\begin{array}{l}80-200 \\
\times 172-280\end{array}$ & $\begin{array}{l}110-170 \\
\times 80-110\end{array}$ & $\begin{array}{l}80-130 \\
\times 40-50\end{array}$ & $\begin{array}{l}119-160 \\
\times 74-101\end{array}$ \\
\hline Ovary: width & $200-240$ & $70-140$ & $90-170$ & - & - & - & - & $200-388$ & $110-190$ & 140 & $437-503$ \\
\hline Uterus: shape & $\begin{array}{l}\text { horseshoe- } \\
\text { shape }\end{array}$ & saccate & $\begin{array}{l}\text { bilobed } \\
\text { sac }\end{array}$ & $\begin{array}{l}\text { saccate, } \\
\text { with diver- } \\
\text { ticula* }\end{array}$ & $\begin{array}{l}\text { bilobed } \\
\text { sac }\end{array}$ & $\begin{array}{l}\text { bilobed } \\
\text { sac }\end{array}$ & - & $\begin{array}{l}\text { bilobed } \\
\text { sac }\end{array}$ & $\begin{array}{l}\text { saccate, } \\
\text { with diver- } \\
\text { ticula }\end{array}$ & $\begin{array}{l}\text { saccate, } \\
\text { with diver- } \\
\text { ticula }\end{array}$ & $\begin{array}{l}\text { saccate, } \\
\text { with di- } \\
\text { verticula }\end{array}$ \\
\hline Egg: size & $78 \times 81$ & $40-70$ & $50-90$ & - & - & - & - & $67-72$ & - & $32-45$ & $\begin{array}{l}55-61 \\
\times 56-63\end{array}$ \\
\hline Egg: shape & spherical & spherical & spherical & - & - & spherical* & - & - & - & spherical & spherical \\
\hline Oncosphere: size & $30 \times 26$ & - & - & - & - & - & - & $34-38$ & - & - & $\begin{array}{l}27-38 \\
\times 37-41\end{array}$ \\
\hline Embryonic hook: size & 14.8 & $25-35$ & - & - & - & - & - & - & - & - & $13-15$ \\
\hline References & $\begin{array}{l}\text { Nybelin } \\
\text { (1917) }\end{array}$ & $\begin{array}{l}\text { Beveridge } \\
\text { and } \\
\text { Barker } \\
(1975)\end{array}$ & $\begin{array}{l}\text { Beveridge } \\
\text { and } \\
\text { Barker } \\
(1975)\end{array}$ & $\begin{array}{l}\text { Vaucher } \\
\text { et al. } \\
\text { (1984) }\end{array}$ & $\begin{array}{l}\text { Vaucher } \\
\text { et al. } \\
(1984)\end{array}$ & $\begin{array}{l}\text { Vaucher } \\
\text { et al. } \\
\text { (1984) }\end{array}$ & $\begin{array}{l}\text { Vaucher } \\
\text { et al. } \\
(1984)\end{array}$ & $\begin{array}{l}\text { Jones and } \\
\text { Anderson } \\
\text { (1990) }\end{array}$ & $\begin{array}{l}\text { Vaucher } \\
\text { and } \\
\text { Beveridge } \\
\text { (1997) }\end{array}$ & $\begin{array}{l}\text { Vaucher } \\
\text { and } \\
\text { Beveridge } \\
(1997)\end{array}$ & $\begin{array}{l}\text { present } \\
\text { study }\end{array}$ \\
\hline
\end{tabular}

* Characters observed in the present study.

However, revision of Vampirolepis is beyond the scope of the present study. Herein, we differentiate $P$. gulyaevi from some Vampirolepis (sensu lato) species because we believe that the latter genus may include cestodes that should belong to Potorolepis.

There are several species of Vampirolepis from bats, which may be similar to $P$. gulyaevi based on the armature of rhynchus. These are V. guarany (Rego, 1961) in Molossus molossus (Pallas) (syn. Molossus crassicaudatus Geoffroy) and Molossus sp. from South America; V. isensis Sawada, 1966 in Rhinolophus cornutus Temminck, $R$. ferrumequinum (Schreber) and $R$. monoceros Andersen from Taiwan and Japan; V. kobayashii Sawada, Harada et Kobayashi, 1984 in Rhinolophus creaghi Thomas from Malaysia; and $V$. acollaris Sawada et Harada, 1985 in Rhinolophus coelophyllus Peters from Thailand. The size of rostellar hooks of $P$. gulyaevi is close to those in $V$. guarany (50 $\mu \mathrm{m}$ according to Rego 1962 and 46-52 $\mu \mathrm{m}$ according to Vaucher 1986). However, V. guarany should be excluded from potential congeners of the new species since it has characters of Vampirolepis (fraternoid rostellar hooks and testes situated in one row and not separated by female gonads).

Vampirolepis isensis, $V$. acollaris and $V$. kobayashii are similar to P. gulyaevi based on the shape of the ros- tellar hooks. Potorolepis gulyaevi is distinguished from these three species by a smaller number of rostellar hooks (22-25 in V. isensis, 25 in $V$. acollaris and 20 in $V$. kobayashii) and greater hook length (32 in $V$. isensis, 28-32 in V. acollaris and 38 in V. kobayashii). Potorolepis gulyaevi can be distinguished from $V$. isensis and $V$. kobayashii by the antiporal end of the cirrus-sac that reaches the ventral osmoregulatory canal but rarely overlaps it; in the two latter species the cirrus-sac overlaps the osmoregulatory canal. Furthermore, the testes of $P$. gulyaevi are arranged in a triangle in contrast to those in $V$. isensis, which are situated in a row.

Our comparative studies of the type species, $P$. potoroi and other congeners, and inclusion of $P$. gulyaevi have required amendation of the original generic diagnosis of Potorolepis proposed by Spassky (1994) and then modified by Vaucher and Beveridge (1997). Previously unrecognized but distinctive generic-level characters for $\mathrm{Po}$ torolepis now include attributes of the gravid uterus and structure of the eggs. For example, the gravid uterus may have diverticula in $P$. potoroi (our observations), $P$. peramelidarum (our observations), $P$. aruensis, $P$. woolleyae and $P$. gulyaevi. The eggs are spherical and with a thick outer coat in P. peramelidarum, P. bradleyi, P. woolleyae, $P$. bettongiae (our observations) and $P$. gulyaevi. 


\section{Amended diagnosis Potorolepis Spassky, 1994}

Diagnosis (after Spassky 1994, with modifications): Hymenolepididae of medium size. Development of proglottides gradual. Proglottides numerous, transversely elongate, craspedote. Rhynchus armed with one row of large diorchoid hooks. Suckers unarmed, muscular, commonly not prominent. Dorsal and ventral osmoregulatory canals located on same sagittal plane. Ventral canals without transverse anastomoses. Genital pores unilateral, dextral, genital ducts pass dorsal to osmoregulatory canals. Three testes situated in triangle or in one row; poral testis separated from two antiporal testes by female gonads. Cirrus-sac does not reach median line of proglottis. Cirrus armed or rarely smooth. External and internal seminal vesicles present. Ovary median, usually fan-shaped, lobed, sometimes slightly lobed. Vitellarium postovarian, median, slightly lobed. Uterus initially bilobed sac, fully developed uterus usually with lobes and diverticula not extending beyond osmoregulatory canals. Eggs numerous, spherical or subspherical, with thick outer coat. Embryophore subspherical. Parasites of marsupials and bats in Australasia and Indo-Malaya. Type species: Potorolepis potoroi (Vaucher, Beveridge et Spratt, 1984).

\section{DISCUSSION}

Potorolepis gulyaevi sp. n. represents the first record of this genus in chiropterans and considerably extends distribution area of the genus outside the Australasian region. Previously known geographic range of Potorolepis generally corresponded to the distributions of their definitive hosts in Australia, Tasmania, Aru Islands and New Guinea (Beveridge and Barker 1975, Vaucher et al. 1984, Jones and Anderson 1990, Vaucher and Beveridge 1997). Phylogenetic relationships of these tapeworms with other hymenolepidids are not yet established, and thus currently cannot provide further insights into the evolutionary history of this cestode group. The demonstrated host and geographic range of Potorolepis suggests an association with Marsupialia that may pre-date the breakup of Gondwanaland; such a distribution for the Hymenolepididae was proposed by Beveridge and Jones (2002).

There are no described species of Potorolepis species in marsupials from South America (Schmidt 1986, Gardner and Campbell 1992, Gardner et al. 2003). However, incomplete host sampling and confused taxonomy of these cestodes may obscure the larger biogeographic history for Potorolepis. In this regard, Beveridge and Spratt (2003) made the assumption that some specimens in South American marsupials of the genus Dromisiops Thomas were apparently attributable to Potorolepis. This is of interest given the Trans-Antarctic distributions for species of the anoplocephalid genus Linstowia Zschokke,
1899, which demonstrates ecological continuity and a link between the South American and Australian faunas in the late Cretaceous (Beveridge 1983, Gardner and Campbell 1992).

Potorolepis gulyaevi represents the first member of the genus occurring in non-marsupial hosts and outside the Australasian ecozone. We assume that the occurrence of Potorolepis in bats (Rhinolophus Lacépède) represents an event of host colonization and is an example of the "hostal radiation" of parasites (Hoberg and Brooks 2008). Alternatively, the apparently rare occurrence of this new hymenolepidid in chiropterans may suggest that it has not yet been found in its typical definitive host. Further survey and inventory of cestodes in chiropterans and other small insectivorous mammals is required to completely resolve the relationships of $P$. gulyaevi. Ecological similarity and geographic sympatry for some chiropterans, marsupials and other small mammals suggest the possibility of mutual exchanges of helminths, which may influence the structure of faunas over the evolutionary time.

For example, some hymenolepidids of Australian marsupials are morphologically similar to those of the genus Vampirolepis in bats (see Sawada 1997) as exemplified by Rodentolepis cercarteti (Vaucher, Beveridge et Spratt, 1984). The occurrence of species attributed to Hymenolepis, Rodentolepis and Staphylocystis in various Chiroptera supports the assumption of the important role of hostal radiation in the evolution of hymenolepidids (see Sawada 1997, Makarikova et al. 2010).

A strong volant capacity and dispersal potential of bats allow them overcome significant geographical barriers (including aquatic) that are almost impenetrable for other terrestrial mammals (Breed et al. 2010). In turn, wide distribution of chiropteran hosts could become an important determinant of geographic distributions of their parasitic worms including cestodes. Rhinolophids inhabit temperate and tropical regions from Europe and Africa, to southeast Asia and Japan, to the Philippines, New Guinea and Australia. Phylogenetic analyses suggest that the horseshoe bats arose in Asia or in southeastern Asia and subsequently expanded into Europe and Africa (Maree and Grant 1997, Stoffberga et al. 2010). The oldest fossils of Rhinolophus, however, were recorded from late Oligocene and early Miocene in South Australia (Hall 1989, Sazali et al. 2011). In any case, these data demonstrate that events of Rhinolophus dispersal between Australia and Asia have occurred historically, which provided a basis for the concurrent expansion of their cestode fauna.

In summary, results of the present study do not support the transfer of $V$. isensis, $V$. kobayashii and $V$. acollaris into Potorolepis. Although these three species are similar to $P$. gulyaevi in having diorchoid hooks and also occur in bats of the genus Rhinolophus from East and Southeast Asia, their generic allocation requires additional study. 
Acknowledgements. We are grateful to Mikhail Tiunov for making cestode specimens from bats from Yunnan Province available for this study. We wish to thank the curator of the cestode collections Dr. Jean Mariaux (Natural History Museum, Geneva, Switzerland) for assistance in assembling cestode specimens for the current study. Dr. Eric P. Hoberg, curator of the US National Parasite Collection (Beltsville, Maryland) and Dr. Va- syl V. Tkach (University of North Dakota, Grand Forks, North Dakota), kindly discussed results of ongoing work and provided some editorial assistance on this paper. Research by A.A. Makarikov is funded by the National Science Foundation (PBI grants DEB 0818696 and 0818823 ) coordinated by J. Caira, University of Connecticut in Storrs, USA.

\section{REFERENCES}

Beveridge I. 1983: The genus Linstowia Zschokke, 1899 (Cestoda: Anoplocephalidae) in Australian mammals with the description of a new species, L. macrouri. Syst. Parasitol. 5: 291-304.

Beveridge I., Barker I.K. 1975: Acuariid, capillariid and hymenolepidid parasites of the dasyurid marsupial Antechinus stuartii Macleay, 1841, from southeastern Australia. J. Helminthol. 49: 211-227.

Beveridge I., Jones M.K. 2002: Diversity and biogeographical relationships of the Australian cestode fauna. Int. J. Parasitol. 32: $343-351$

Beveridge I., Spratt D.M. 2003: Parasites of carnivorous marsupials. In: M. Jones, C. Dickman and M. Archer (Eds.), Predators with Pouches: The Biology of Marsupial Carnivores. CSIRO Publishing, Collingwood, pp. 383-396.

Breed A.C., Field H.E., Smith C.S., Edmonston J., Meers J. 2010: Bats without borders: long-distance movements and implications for disease risk management. Ecohealth 7: 204-212.

Czaplinski B., Vaucher C. 1994: Family Hymenolepididae Ariola, 1899. In: L.F. Khalil, A. Jones and R.A. Bray (Eds.), Keys to the Cestode Parasites of Vertebrates. CAB International, Wallingford, pp. 595-663.

Gardner S.L., Campbell M.L. 1992: A new species of Linstowia (Cestoda: Anoplocephalidae) from marsupials in Bolivia. J. Parasitol. 78: 795-799.

Gardner S.L., Campbell M.L., Navone G.T. 2003: A new species of Mathevotaenia (Cestoda: Anoplocephalidae) and other tapeworms from marsupials in Argentina. J. Parasitol. 89: $1181-1185$.

Jones A., Anderson T.J.C. 1990: Helminths of rodents and marsupials from Papua New Guinea, with the description of two new species, Echinostoma echymiperae n. sp. (Digenea: Echinostomatidae) and Vampirolepis peroryctis n. sp. (Cestoda: Hymenolepididae). Syst. Parasitol. 15: 223-237.

Hall L.S. 1989: Rhinolophidae. In: D.W. Walton and B.J. Richardson (Eds.), The Fauna of Australia. Vol. 1B. Mammalia. Australian Government Publishing Service, Canberra, pp. 857-870.

Hoberg E., Brooks D.R. 2008: A macroevolutionary mosaic: episodic host-switching, geographical colonization and diversification in complex host-parasite systems. J. Biogeogr. 35: $1533-1550$.

Makarikova T.A., Gulyaev V.D., Tiunov M.P., Feng Jiang 2010: [Cestodes Paramilina nishidai (Sawada 1982) gen. n., comb. n. and Hymenolepis magna sp. n. (Cyclophyllidea: Hy- menolepididae) from Chiroptera in China.] Zool. Zh. 89: 131139. (In Russian.)

Maree S., Grant W.S. 1997: Origins of horseshoe bats (Rhinolophus, Rhinolophidae) in southern Africa: evidence from allozyme variability. J. Mamm. Evol. 4: 195-215.

Nybelin O. 1917: Results of Dr. E. Mjöbergs Swedish Scientific Expeditions to Australia 1910-1913 XIV. Australische Cestoden. K. Sven. Vetensk. Handlingar 52 (14): 4-48.

REgo A.A. 1962: Sobre alguns "Vampirolepis" parasitos de quiropteros (Cestoda, Hymenolepididae). Rev. Brasil. Biol. 22: 129-136.

SAWADA I. 1997: A World Checklist of Cestode Species from Chiroptera. Published by the author, Nara City, Japan, 65 pp.

Sazali S.N., Besar K., Abdullah M.T. 2011: Phylogenetic analysis of the Malaysian Rhinolopus and Hipposideros inferred from partial mitochondrial DNA cytochrome b gene sequences. Pertanika J. Trop. Agric. Sci. 34: 281-294.

Schмidt G.D. 1986: CRC Handbook of Tapeworm Identification. CRC Press, Boca Raton, Florida, 675 pp.

Spassky A.A. 1954: [Classification of the Hymenolepididae of mammals.] Tr. Gel'mintol. Lab. AN SSSR. 7: 120-167. (In Russian.)

SPASSKY A.A. 1994: [On systematic position of hymenolepidids (Cestoda) from Australian Marsupialia.] Parazitologiya 28: 66-69. (In Russian.)

Stoffberga S., Jacobsa D.S., Mackiec I.J., Mattheeb C.A. 2010: Molecular phylogenetics and historical biogeography of Rhinolophus bats. Mol. Phylogen. Evol. 54: 1-9.

Vaucher C. 1986: Helminthes parasites du Paraguay XI: Hymenolepididae (Cestoda) parasites de chiroptères Molossidae, avec description de deux espèces nouvelles. Rev. Suisse Zool. 93: 393-407.

Vaucher C. 1992: Revision of the genus Vampirolepis Spasskij, 1954 (Cestoda: Hymenolepididae). Mem. Inst. Oswaldo Cruz, Rio de Janeiro 87 (Suppl. 1): 299-304.

Vaucher C., Beveridge I. 1997: New species of Potorolepis Spasskii (Cestoda: Hymenolepididae) parasitic in dasyurid marsupials from New Guinea. Trans. R. Soc. S. Aust. 121: 95-102.

Vaucher C., Beveridge I., Spratt D.M. 1984: Cestodes du genre Hymenolepis Weinland, 1858 (sensu lato) parasites de marsupiaux australiens et description de cinq especès nouvelles. Rev. Suisse Zool. 91: 443-458. 